\title{
2001 INDEX BY SUBJECT
}

A

\section{Aboriginal people}

The Aboriginal men's health implementation plan (Williams V, Kakakios M) 2001 12(12), 318-321

adolescents, see also children

Development of a child and youth health report card for Central Sydney, 2000 (O’Sullivan B et al.) 2001 12(11), 302-307

Getting in early: a framework for early intervention and prevention in mental health for young people in New South Wales (Paterson K et al.) 2001 12(05), 137

\section{anthrax}

factsheet 2001 12(12), 338

monthly updates 2001 12(01), 20

arboviral diseases

Arbovirus activity (Russell R et al.) 2001 12(05), 143-144

monthly updates 2001 12(06), 175-176

\section{asthma}

Time trends in emergency department presentations of children with acute severe asthma in NSW (Lincoln D, Muscatello D) 2001 12(11), 293-295

Using NSW health survey data to monitor asthma prevalence and management in NSW (Marks G) 2001 12(08), 221-223

Australian Bureau of Statistics

Health surveys conducted by the Australian Bureau of Statistics (Atyeo P, Rawson M) 2001 12(08), 237-239

\section{B}

\section{biological warfare}

Assuming the worst: responding to episodes of suspected biological terrorism (Leask A et al.) 2001 12(12), 339

\section{breast cancer}

A successful volunteer program showcased during the international year of volunteering: the Cancer Council NSW's Breast Cancer Support Service (Burton L et al.) 2001

Estimating a woman's risk of breast cancer: the effects of age and family history (Taylor R et al.) 2001 12(02), 36-40

Interval breast cancers in New South Wales (Taylor $\mathrm{R}$ et al.) 2001 12(04), 102-105

Multidisciplinary care for women with breast cancer: a national demonstration program (Luxford K, Rainbird K) 2001 12(10), $277-279$

Using linked data to explore quality of care for breast cancer (Kricker A) 2001 12(04), 110-113

Using record linkage to measure trends in breast cancer surgery C (Churches T, Lim, K) 2001 12(04), 105-110

cancer, see also specific cancers, e.g. breast cancer

Area cancer control network: from cottage industry to strategic care (Tynan K et al.) 2001 12(10), 266-269

Better information for radiation oncology (Looyschelder S) 2001 12(02), 33-36

Cancer in NSW: incidence and mortality 1997 (Coates M, Tracey, E) 2001 12(02), 40-42

Cancer patients' supportive care needs: strategies for assessment and intervention (Girgis A, Burton L) 2001 12(10), 269272

Cancer prevention by diet and exercise (Mitchell JA, Armstrong B) 2001 12(01), 7-9

Measuring risk factors that can be modified to prevent cancer (Moore $\mathrm{H}$ et al.) 2001 12(01), 2-6

Measuring the performance of cancer services: guest editorial (Armstrong B) 2001 12(04), 93-94

Models of cancer care and support in NSW: guest editorial (Girgis A) 2001 12(10), 265-266
Psychosocial guidelines in cancer care and support (Turner J) 2001 12(10), 274-276

Status report on redeveloping the NSW Central Cancer Registry (Tracey E) 2001 12(02), 26-28

Sustaining action to prevent cancer:guest editorial (King L) $200112(03), 69$

Taking action to prevent cancer in NSW: guest editorial (King L) 2001 12(01), 1-2

The future is now: new and better cancer information in NSW: guest editorial 2001 12(02), 25-26

The importance of communication skills to effective cancer care and support (Butow P) 2001 12(10), 272-274

Towards a clinical cancer information system (Noworytko $\mathrm{H}$ et al.) 2001 12(02), 28-32

care, see also primary health care

A successful volunteer program showcased during the international year of volunteering: the Cancer Council NSW's Breast Cancer Support Service (Burton L et al.) 2001

Area cancer control network: from cottage industry to strategic care (Tynan K et al.) 2001 12(10), 266-269

Cancer patients' supportive care needs: strategies for assessment and intervention (Girgis A, Burton L) 2001 12(10), 269272

Informal caring in Central Sydney (Muscatello D et al.) 2001 12(01), 12-13

Multidisciplinary care for women with breast cancer: a national demonstration program (Luxford K, Rainbird K) 2001 12(10), 277-279

Psychosocial guidelines in cancer care and support (Turner J) 2001 12(10), 274-276

The importance of communication skills to effective cancer care and support (Butow P) 2001 12(10), 272-274

\section{cervical cancer}

The role of the NSW Pap Test Register in monitoring the cervical screening process in NSW (Macansh S) 2001 12(04), 99102

children, see also adolescents; immunisation; lead

Development of a child and youth health report card for Central Sydney, 2000 (O'Sullivan B et al.) 2001 12(11), 302-307

The wellbeing of boys (Fletcher R) 2001 12(12), 324-326

Clinical Information Access Program (CIAP)

What's new on the CIAP Web site (Wensley M) 2001 12(02), 44

communicable diseases, see also names of specific diseases and organisms. (Note: Communicable diseases updates appear in every issue of the Bulletin and are not indexed)

Survey of public swimming pools in the Mid Western Area Health Service: 2000-2001 (Thorne J) 2001 12(11), 299302

communication

The importance of communication skills to effective cancer care and support (Butow P) 2001 12(10), 272-274

\section{Creutzfeldt-Jakob disease}

factsheet 2001 12(02), 43

cryptosporidiosis

factsheet 2001 12(05), 142

D

data collection, see also notifications; population data; surveys

Area cancer control network: from cottage industry to strategic care (Tynan K et al.) 2001 12(10), 266-269

Continuous data collection under the NSW health survey program —what will it mean? (Eyeson-Annan M) 2001 12(08), 235-237 
Development of a child and youth health report card for Central Sydney, 2000 (O'Sullivan B et al.) 2001 12(11), 302-307

Status report on redeveloping the NSW Central Cancer Registry (Tracey E) 2001 12(02), 26-28

The experience of the Well Person's Health Check in the Far West Area Health Service (Jackson L et al.) 2001 12(06), $152-155$

The future is now: new and better cancer information in NSW: guest editorial 2001 12(02), 25-26

Towards a clinical cancer information system (Noworytko $\mathrm{H}$ et al.) 2001 12(02), 28-32

Using linked data to explore quality of care for breast cancer (Kricker A) 2001 12(04), 110-113

Using record linkage to measure trends in breast cancer surgery (Churches T, Lim, K) 2001 12(04), 105-110

\section{databases}

Using the International Classification of Diseases with HOIST (Muscatello D, Travis S) 2001 12(11), 289-293

\section{diabetes}

Prevalence and management of diabetes in NSW: is care adhering to clinical guidelines? (Williamson M, Quaine J) 2001 12(08), 223-225

\section{diet and nutrition}

Cancer prevention by diet and exercise (Mitchell JA, Armstrong B) 2001 12(01), 7-9

Increasing the consumption of vegetables and fruit: a national public health call to action (Vita P et al.) 2001 12(01), 9-11

Taking action to prevent cancer in NSW: guest editorial (King L) 2001 12(01), 1-2

doctors, see also general practice

Rural medical education: helping to solve the rural workforce crisis (Khadra M) 2001 12(06), 162-164

E

\section{emergency care}

The impact of a general practice staffed casualty service on overall primary medical services (Bolton P et al.) 2001 12(11), 296-298

Time trends in emergency department presentations of children with acute severe asthma in NSW (Lincoln D, Muscatello D) 2001 12(11), 293-295

enteroviral diseases

Enterovirus 71 (Delpech V et al.) 2001 12(05), 143

\section{epireviews}

Hepatitis A in New South Wales, 1991-2000: epireview (Delpech V et al.) 2001 12(09), 255-258

Hepatitis C in NSW, 1991-1999: epireview (Delpech V et al.) 2001 12(05), 139-141

Legionnaires' disease, NSW, 1991-2000 (McAnulty J et al.) 2001 12(10), 282-285

Measles in NSW, 1991-2000 (Brotherton J) 2001 12(07), 200204

Notifiable sexually transmissible diseases, NSW 1991-1999: epireview 2001 12(01), 16-18

Notifications of Q fever in New South Wales, 1991-2000: epireview (Lin M et al.) 2001 12(06), 172-175

Rubella in NSW 1991-2000: epireview (Brotherton J, Habib

$\mathbf{F}$ M) 2001 12(03), 85-87

\section{factsheets}

Anthrax 2001 12(12), 338

Creutzfeld-Jakob disease 2001 12(02), 43

Cryptosporidiosis 2001 12(05), 142

Giardiasis 2001 12(06), 171

Hepatitis B 2001 12(09), 259-260

Legionnaires disease 2001 12(03), 88
Listeriosis 2001 12(11), 308

Measles 2001 12(07), 199

Murray Valley encephalitis (Australian encephalitis 2001 12(04), 114

Psittacosis 2001 12(01), 19

Rubella 2001 12(08), 240

foot-and-mouth disease

Foot-and-mouth disease: public health implications (Oakman T) 2001 12(07), 206

G

general practice, see also doctors

Men's use of general practitioner services (Woods M) 2001 12(12), 334-335

The impact of a general practice staffed casualty service on overall primary medical services (Bolton P et al.) 2001 12(11), 296-298

giardiasis

factsheet 2001 12(06), 171

globalisation

Globalisation: where do we go from here (Stilwell F) 2001 12(07), 183-185

Taking responsibility to address inequalities in health (Wise M) 2001 12(07), 186-189

government

How can a government research and development initiative contribute to reducing health inequalities (Dixon J, Sibthorpe B) 2001 12(07), 189-191

\section{H}

\section{health promotion}

Increasing the consumption of vegetables and fruit: a national public health call to action (Vita P et al.) 2001 12(01), 9-11

\section{health services}

Building capacity in rural health (Lyle D, Kerr C) 2001 12(06), 159-161

Measuring the performance of cancer services: guest editorial (Armstrong B) 2001 12(04), 93-94

Men's perceived health needs (Fletcher R et al.) 2001 12(12), 327-329

Policy development in the rural sector: a personal perspective (Douglas M) 2001 12(06), 150-152

Working out what to measure: melanoma services (Moore $\mathrm{H}$ et al.) 2001 12(04), 94-99

\section{health status}

Electronic report of the NSW health surveys 1997 and 1998 (Jorm L) 2001 12(05), 138

Global health inequalities: the challenge to epidemiology (McKee M) 2001 12(05), 130-133

Health inequalities: something old, something new: guest editorial (Sainsbury P, Harris, E) 2001 12(05), 117-119

Measuring health inequalities in New South Wales (Moore H, Jorm, L) 2001 12(05), 120-125

Socioeconomic differentials in life expectancy and years of life lost in Victoria, 1992-1996 (Vos T et al.) 2001 12(05), 126130

hepatitis

Hepatitis A in New South Wales, 1991-2000: epireview (Delpech V et al.) 2001 12(09), 255-258

Hepatitis B: factsheet 2001 12(09), 259-260

Hepatitis C in NSW, 1991-1999: epireview (Delpech V et al.) 2001 12(05), 139-141

\section{HIV/AIDS}

20 years of AIDS 2001 12(07), 207-208

Surveillance for human immunodeficiency virus infection, NSW, to September 20012001 12(12), 340-341 


\section{HOIST (Health Outcomes and Information Statistical \\ Toolkit)}

Using the International Classification of Diseases with HOIST (Muscatello D, Travis S) 2001 12(11), 289-293

\section{hospitalisation}

Identifying work-related injury and disease in routinely collected

NSW hospitalisation data (Muscatello D, Mitchell R) 2001

12(07), 195-198

I

\section{immunisation}

Australian Childhood Immunisation Register - quarterly report 2001 12(12), 339

Quarterly report: Australian Childhood Immunisation Register 2001 12(11), 309

\section{income, see socioeconomic factors}

infectious diseases, see also names of specific diseases and organisms. (Note: Communicable diseases updates appear in every issue of the Bulletin and are not indexed)

Survey of public swimming pools in the Mid Western Area Health Service: 2000-2001 (Thorne J) 2001 12(11), 299302

\section{influenza}

Influenza in NSW, 2001 (Menzies R et al.) 2001 12(11), 309 monthly updates 2001 12(01), 20; 2001 12(10), 285

NSW influenza surveillance 2001 12(06), 175

\section{information}

The NSW men's health information and resource centre (Brown A et al.) 2001 12(12), 333-334

International Classification of Diseases (ICD)

Using the International Classification of Diseases with HOIST (Muscatello D, Travis S) 2001 12(11), 289-293

\section{Internet}

Release of an HTML version of the Bulletin and changes to the Bulletin home page 2001 12(09), 245-246

\section{L}

lead

NSW Lead Management Program in Broken Hill (Lyle D et al.) 2001 12(06), 165-167

legionnaires' disease

factsheet 2001 12(03), 88

Legionnaires' disease, NSW, 1991-2000 (McAnulty J et al.) 2001 12(10), 282-285

monthly updates 2001 12(09), 260

listeriosis

factsheet 2001 12(11), 308

Lyssavirus infections

monthly updates 2001 12(01), 20

\section{M}

\section{mammograms}

Interval breast cancers in New South Wales (Taylor R et al.) 2001 12(04), 102-105

\section{measles}

factsheet 2001 12(07), 199

Measles in NSW, 1991-2000 (Brotherton J) 2001 12(07), 200204

monthly updates 2001 12(08), 241

melanoma, see also sun protection

Working out what to measure: melanoma services (Moore $\mathrm{H}$ et al.) 2001 12(04), 94-99

men

A population health approach to men's health: guest editorial (Macdonald J) 2001 12(12), 313-315

Males and mental health: a public health approach (Nielsen B et al.) 2001 12(12), 330-332
Men's health - the way forward (Kakakios M) 2001 12(12), 315-317

Men's perceived health needs (Fletcher R et al.) 2001 12(12), 327-329

Men's use of general practitioner services (Woods M) 2001 12(12), 334-335

The Aboriginal men's health implementation plan (Williams V, Kakakios M) 2001 12(12), 318-321

The health of men in NSW (Gizzi M, Monaem A) 2001 12(12), 322-324

The NSW men's health information and resource centre (Brown A et al.) 2001 12(12), 333-334

The NSW men's health network (Sliwka G) 2001 12(12), 336337

The wellbeing of boys (Fletcher R) 2001 12(12), 324-326

meningococcal disease

monthly updates 2001 12(08), 241; 2001 12(09), 260; 2001 12(10), 285

Men's Health Information and Resource Centre (MHIRC)

The NSW men's health information and resource centre (Brown A et al.) 2001 12(12), 333-334

Men's Health Network (MHN)

The NSW men's health network (Sliwka G) 2001 12(12), 336337

mental illness, see also suicide

Getting in early: a framework for early intervention and prevention in mental health for young people in New South Wales (Paterson K et al.) 2001 12(05), 137

Males and mental health: a public health approach (Nielsen B et al.) 2001 12(12), 330-332

Promotion, prevention and early intervention in mental health: two new national documents (Scanlon K et al.) 2001 12(05), $136-137$

mortality

Cancer in NSW: incidence and mortality 1997 (Coates M, Tracey, E) 2001 12(02), 40-42

Global health inequalities: the challenge to epidemiology (McKee M) 2001 12(05), 130-133

Socioeconomic differentials in life expectancy and years of life lost in Victoria, 1992-1996 (Vos T et al.) 2001 12(05), 126130

Murray Valley encephalitis

monthly updates 2001 12(03), 89

Murray Valley encephalitis (Australian encephalitis): factsheet 2001 12(04), 114

mycobacterial infections

monthly updates 2001 12(01), 21

$\mathbf{N}$

\section{New South Wales}

Tackling health inequalities in the NSW health system: the NSW Health and Equity Statement (Hyde J) 2001 12(07), 192193

The health of men in NSW (Gizzi M, Monaem A) 2001 12(12), 322-324

Uses of NSW health survey program data - a survey of users (Banks C, Eyeson-Annan M) 2001 12(08), 214-220

Using NSW Health Survey data for local planning and evaluation in NSW (Rissel C) 2001 12(08), 226-227

non-English speaking backgrounds

Collecting information from people of non-English speaking background: translation of survey instruments in the NSW health survey program (Baker D) 2001 12(08), 231-233

notifications, see also data collection

monthly updates 2001 12(01), 20-21

The National Notifiable Diseases Surveillance System 2001 12(06), 176 


\section{NSW Central Cancer Registry (ClinCRs)}

Status report on redeveloping the NSW Central Cancer Registry (Tracey E) 2001 12(02), 26-28

Towards a clinical cancer information system (Noworytko $\mathrm{H}$ et al.) 2001 12(02), 28-32

\section{NSW Health}

NSW Health becomes a registered training organisation (Hartley R) 2001 12(06), 167-170

\section{NSW Public Health Bulletin}

Release of an HTML version of the Bulletin and changes to the Bulletin home page 2001 12(09), 245-246

\section{nutrition, see diet and nutrition}

\section{O}

\section{occupational health}

Identifying work-related injury and disease in routinely collected NSW hospitalisation data (Muscatello D, Mitchell R) 2001 12(07), 195-198

The health of the people in agriculture and its interdependence with the health of rural communities (Fragar L) 2001 12(06), $155-159$

\section{P}

\section{pap smears}

The role of the NSW Pap Test Register in monitoring the cervical screening process in NSW (Macansh S) 2001 12(04), 99-102

pertussis (whooping cough)

monthly updates 2001 12(01), 20; 2001 12(09), 260; 2001 12(10), 285

\section{physical activity}

Cancer prevention by diet and exercise (Mitchell JA, Armstrong B) 2001 12(01), 7-9

\section{pneumococcal infection}

Invasive pneumococcal disease in NSW (Brotherton J, Campbell-Lloyd S) 2001 12(07), 205-206

monthly updates 2001 12(01), 20

policy development

'Evidence from systematic reviews of research relevant to implementing the wider public health agenda' (book review) (Sainsbury P) 2001 12(05), 138

Tackling health inequalities in the NSW health system: the NSW Health and Equity Statement (Hyde J) 2001 12(07), 192193

Tackling inequalities: research, policy, practice and advocacy: guest editorial (Harris E, Sainsbury P) 2001 12(07), 181182

Taking responsibility to address inequalities in health (Wise M) 2001 12(07), 186-189

\section{population data, see also data collection}

A population health approach to men's health: guest editorial (Macdonald J) 2001 12(12), 313-315

Getting population health research to influence health service practice: use of area health service questions in the NSW health survey (Quaine J et al.) 2001 12(08), 229-231

Health surveys: building an information base for population health in NSW: guest editorial (Jorm L) 2001 12(08), 213214

Uses of NSW health survey program data - a survey of users (Banks C, Eyeson-Annan M) 2001 12(08), 214-220

primary health care, see also care

The experience of the Well Person's Health Check in the Far West Area Health Service (Jackson L et al.) 2001 12(06), 152-155

The impact of a general practice staffed casualty service on overall primary medical services (Bolton P et al.) 2001 12(11), 296-298

\section{prison populations}

Managing a tobacco control program in NSW correctional centres, 1999-2001 (Awofeso N et al.) 2001 12(07), 193195

psittacosis

factsheet $200112(01), 19$

monthly updates 2001 12(01), 20

public health

'Evidence from systematic reviews of research relevant to implementing the wider public health agenda' (book review) (Sainsbury P) 2001 12(05), 138

How can a government research and development initiative contribute to reducing health inequalities (Dixon J, Sibthorpe B) 2001 12(07), 189-191

Tackling inequalities: research, policy, practice and advocacy: guest editorial (Harris E, Sainsbury P) 2001 12(07), 181182

Q

$Q$ fever

Notifications of Q fever in New South Wales, 1991-2000: epireview (Lin M et al.) 2001 12(06), 172-175

$\mathbf{R}$

\section{radiation oncology}

Better information for radiation oncology (Looyschelder S) 2001 12(02), 33-36

research

Getting population health research to influence health service practice: use of area health service questions in the NSW health survey (Quaine J et al.) 2001 12(08), 229-231

How can a government research and development initiative contribute to reducing health inequalities? (Dixon J, Sibthorpe B) 2001 12(07), 189-191

resource allocation

Using NSW Health Survey data for economic analysis (Haas M) 2001 12(08), 227-228

\section{risk factors}

Estimating a woman's risk of breast cancer: the effects of age and family history (Taylor $\mathrm{R}$ et al.) 2001 12(02), 36-40

Measuring risk factors that can be modified to prevent cancer (Moore $\mathrm{H}$ et al.) 2001 12(01), 2-6

rubella

Rubella in NSW 1991-2000: epireview (Brotherton J, Habib M) 2001 12(03), 85-87

factsheet 2001 12(08), 240

rural health

Building capacity in rural health (Lyle D, Kerr C) 2001 12(06), 159-161

Policy development in the rural sector: a personal perspective (Douglas M) 2001 12(06), 150-152

Rural health in NSW: guest editorial (Kerr C) 2001 12(06), 149-150

Rural medical education: helping to solve the rural workforce crisis (Khadra M) 2001 12(06), 162-164

The experience of the Well Person's Health Check in the Far West Area Health Service (Jackson L et al.) 2001 12(06), 152-155

The health of the people in agriculture and its interdependence with the health of rural communities (Fragar L) 2001 12(06), 155-159

S

screening, see also mammograms; pap smears

The experience of the Well Person's Health Check in the Far West Area Health Service (Jackson L et al.) 2001 12(06), 152-155 
The role of the NSW Pap Test Register in monitoring the cervical screening process in NSW (Macansh S) 2001 12(04), 99102

sexually transmitted diseases, see also specific diseases, e.g. HIV/AIDS

Notifiable sexually transmissible diseases, NSW 1991-1999: epireview 2001 12(01), 16-18

shigella

monthly updates 2001 12(01), 20-21

skin cancer, see also melanoma

A strategic framework for skin cancer prevention for NSW (Ferguson C, Vita P) 2001 12(03), 75-77

The role of shade in skin cancer prevention (Soulos G) 2001 12(03), 78-80

\section{smoking}

Advocacy for tobacco control (Penman A) 2001 12(03), 7274

Managing a tobacco control program in NSW correctional centres, 1999-2001 (Awofeso N et al.) 2001 12(07), 193195

The current framework for tobacco control (O’Neill C) 2001 12(03), 70-72

\section{socioeconomic factors}

Global health inequalities: the challenge to epidemiology (McKee M) 2001 12(05), 130-133

Globalisation: where do we go from here (Stilwell F) 2001 12(07), 183-185

Health inequalities: something old, something new: guest editorial (Sainsbury P, Harris, E) 2001 12(05), 117-119

How can a government research and development initiative contribute to reducing health inequalities (Dixon J, Sibthorpe B) 2001 12(07), 189-191

Income inequality trends in the 1980s and 1990s (Harding A) 2001 12(05), 134-136

Measuring health inequalities in New South Wales (Moore H, Jorm, L) 2001 12(05), 120-125

Socioeconomic differentials in life expectancy and years of life lost in Victoria, 1992-1996 (Vos T et al.) 2001 12(05), 126130

Tackling health inequalities in the NSW health system: the NSW Health and Equity Statement (Hyde J) 2001 12(07), 192193

Tackling inequalities: research, policy, practice and advocacy: guest editorial (Harris E, Sainsbury P) 2001 12(07), 181182

Taking responsibility to address inequalities in health (Wise M) 2001 12(07), 186-189

suicide

Suicide in New South Wales: the NSW suicide data report (Ansari G et al.) 2001 12(03), 80-84

sun protection, see also melanoma

A strategic framework for skin cancer prevention for NSW (Ferguson C, Vita P) 2001 12(03), 75-77

The role of shade in skin cancer prevention (Soulos G) 2001 12(03), 78-80

surgery

Using linked data to explore quality of care for breast cancer (Kricker A) 2001 12(04), 110-113

Using record linkage to measure trends in breast cancer surgery (Churches T, Lim, K) 2001 12(04), 105-110 surveys, see also data collection

Collecting information from people of non-English speaking background: translation of survey instruments in the NSW health survey program (Baker D) 2001 12(08), 231-233

Continuous data collection under the NSW health survey program-what will it mean? (Eyeson-Annan M) 2001 12(08), 235-237

Electronic report of the NSW health surveys 1997 and 1998 (Jorm L) 2001 12(05), 138

Getting population health research to influence health service practice: use of area health service questions in the NSW health survey (Quaine J et al.) 2001 12(08), 229-231

Health surveys conducted by the Australian Bureau of Statistics (Atyeo P, Rawson M) 2001 12(08), 237-239

Health surveys: building an information base for population health in NSW: guest editorial (Jorm L) 2001 12(08), 213214

Informal caring in Central Sydney (Muscatello D et al.) 2001 12(01), 12-13

Maximising quality in health surveys: lessons from the field (Gorringe M, Latham L) 2001 12(08), 234-235

Uses of NSW health survey program data - a survey of users (Banks C, Eyeson-Annan M) 2001 12(08), 214-220

Using NSW Health Survey data for economic analysis (Haas M) 2001 12(08), 227-228

Using NSW Health Survey data for local planning and evaluation in NSW (Rissel C) 2001 12(08), 226-227

Using NSW health survey data to monitor asthma prevalence and management in NSW (Marks G) 2001 12(08), 221-223

\section{swimming pools}

Survey of public swimming pools in the Mid Western Area Health Service: 2000-2001 (Thorne J) 2001 12(11), 299302

\section{$\mathbf{T}$}

\section{tinnitus}

Tinnitus awareness kit for health professionals 2001 12(06), 170

tobacco sales, see also smoking

Advocacy for tobacco control (Penman A) 2001 12(03), 7274

The current framework for tobacco control (O'Neill C) 2001 12(03), 70-72

\section{training}

NSW Health becomes a registered training organisation (Hartley R) 2001 12(06), 167-170

Rural medical education: helping to solve the rural workforce crisis (Khadra M) 2001 12(06), 162-164

\section{V}

\section{visual impairment}

Vision 2020: the right to sight -Australia (Evans $\mathrm{K}$ et al.) 2001 12(01), 14-15

\section{volunteers}

A successful volunteer program showcased during the international year of volunteering: the Cancer Council NSW's Breast Cancer Support Service (Burton L et al.) 2001

W

whooping cough, see pertussis 


\section{INDEX BY AUTHOR}

A

Alperstein G 200112 (11), 302

Ansari G 200112 (03), 80

Armstrong B 200112 (01), 7 200112 (02), 25, 28 200112 (04), 93, 94

Atyeo P

200112 (08), 237

Awofeso N 200112 (07), 193

\section{B}

Baker D 200112 (08), 231

Balding B 200112 (06), 165

Banks C

200112 (08), 214

Barton M

200112 (10), 266

Begg $S$

200112 (05), 126

200112 (06), 165

Bolton P

200112 (11), 298

Boomer M

200112 (12), 339

Boyages J

200112 (02), 36

Brotherton J

200112 (03), 85

200112 (07), 200, 205

Brown A

200112 (12), 333

Burke H

200112 (06), 152, 165

Burton L

200112 (10), 269, 280

Butow P

200112 (10), 272

C

Campbell-Lloyd $\mathbf{S}$

200112 (06), 172

200112 (07), 205

Chen Y

200112 (05), 126

Chipps J

200112 (03), 80

Churches T

200112 (04), 105

Coates $M$

200112 (02), 40

Crawford D

200112 (12), 333

D

Dagg B

200112 (05), 137
Delpech V

$200112(01), 16$

200112 (05), 139, 143

200112 (06), 172

200112 (09), 255

200112 (10), 282

200112 (11), 309

200112 (12), 339

Dixon J

200112 (07), 189

Dobson A

200112 (12), 327

Doggett $S$

200112 (05), 143

Douglas M

200112 (06), 150

Dwyer D

$200112(05), 143$

E

Estoesta J

200112 (04), 102

Evans K

200112 (01), 14

Eyeson-Annan $M$

200112 (08), 214, 235

F

Ferguson $\mathbf{C}$ 200112 (03), 75

Fletcher R 200112 (12), 324, 327

Fragar L

200112 (06), 155

G

Girgis A

200112 (10), 265, 269, 280

Gizzi M

200112 (12), 322

Gorringe $M$

200112 (08), 234

Griggs E

200112 (11), 309

H

Haas M

200112 (08), 227

Habib M

200112 (01), 16

$200112(03), 85$

$200112(05), 139$

200112 (09), 255

200112 (10), 282

Harding A

200112 (05), 134

Harris E

200112 (05), 117

200112 (07), 181

Hartley R

200112 (06), 167

Heard G

200112 (02), 36
Higginbotham N 200112 (12), 327

Holden B

200112 (01), 14

Hueston $\mathbf{L}$

200112 (05), 143

Hyde J

200112 (07), 192

$J$

Jackson L

200112 (06), 152

Jones JE

200112 (05), 137

Jones M

200112 (11), 296

Jorm L

$200112(01), 2$

$200112(05), 120,138$

200112 (08), 213

K

Kakakios M

200112 (12), 315, 318

Katrakis E

200112 (12), 330

Kerr C

200112 (06), 149, 159

Khadra M

200112 (06), 162

King $\mathbf{L}$

$200112(01), 1$

$200112(03), 69$

Kricker A

200112 (04), 110

Kricker W

200112 (10), 266

L

Latham L

200112 (08), 234

Leask A

200112 (12), 339

Levy MH

200112 (07), 193

Lim K

200112 (04), 105

Lin M

200112 (06), 172

200112 (09), 255

Lincoln D

200112 (11), 293

Lonie C

200112 (04), 94

Looyschelder $\mathbf{S}$ 200112 (02), 33

Luxford K 200112 (10), 277

Lyle D

200112 (06), 159, 165

M

Macansh S

200112 (04), 99
Macoun E

200112 (01), 9

Magnus A

200112 (05), 126

Mahmic Ajsa

200112 (11), 302

Marks G

200112 (08), 221

Mayne D

200112 (06), 152

McAnulty $\mathbf{J}$

200112 (01), 16

$200112(05), 139$

200112 (06), 172

200112 (09), 255

200112 (10), 282

McDermott D

200112 (12), 333

McDonald J

200112 (12), 313

McKee $M$

200112 (05), 130

Menzies R

200112 (11), 309

Mira M

200112 (11), 298

Mitchell E

200112 (12), 339

Mitchell J A

200112 (01), 7

Mitchell R

200112 (07), 195

Monaem A

200112 (12), 322

Moore H

200112 (01), 2

200112 (02), 28

200112 (04), 94

200112 (05), 120

Morris S

200112 (07), 193

Moxon J

$200112(01), 9$

Muscatello D

$200112(01), 12$

200112 (07), 195

200112 (11), 289, 293

$\mathbf{N}$

Neilsen B

200112 (12), 330

Nicholls $C$

200112 (01), 14

Noworytko $\mathbf{H}$

200112 (02), 28

$200112(04), 94$

0

Oakman T

200112 (07), 206

O'Neill C

200112 (03), 70

O'Sullivan B 
$200112(11), 302$

200112 (12), 339

P

Paterson K

200112 (05), 136, 137

Penman A

200112 (03), 72

Q

Quaine J

200112 (08), 223, 229

$\mathbf{R}$

Rainbird K

200112 (10), 277

Rankin N

200112 (10), 280

Raphael B

200112 (05), 136, 137

200112 (12), 330

Rawlinson WD

200112 (05), 143

Rawson M

200112 (08), 237

\section{Rickard M}

200112 (04), 102

Rissel C

$200112(01), 12$

200112 (08), 226

Russell R

200112 (05), 143

\section{S}

Sainsbury $\mathbf{P}$

200112 (01), 12

200112 (05), 117, 138

200112 (07), 181

200112 (08), 229

Scanlon K

200112 (05), 136, 137

Sibthorpe B 200112 (07), 189

Sliwka G

200112 (12), 336

Soulos G

200112 (03), 78

Stewart G

200112 (03), 80

\section{Stilwell F}

200112 (07), 183

Supramaniam R

200112 (04), 102

T

Taylor R

200112 (02), 36

200112 (04), 102

Thorne J

200112 (11), 299

Tracey E

200112 (02), 26, 40

Travis S

200112 (11), 289

Turner J

200112 (10), 274

Tynan K

200112 (10), 266

V

Vita $P$

$200112(01), 2,9$

$200112(03), 75$
Vos T

200112 (05), 126

W

Weeden A

200112 (10), 280

Wensley $M$

200112 (02), 44

Williams V

200112 (12), 318

Williamson $\mathbf{M}$

200112 (08), 223, 229

Wise M

200112 (07), 186

Woods M

200112 (12), 334

Y

Young LC

200112 (05), 143 